\title{
PREVALENCE OF RESPIRATORY SYMPTOMS AND SPIROMETRIC VALUES IN ALUMINIUM POTROOM WORKERS*
}

\author{
Ljiljana CVEJANOV KEZUNOVIĆ \\ Medical School of Podgorica, Podgorica, Montenegro \\ Received in September 2007 \\ Accepted in May 2008
}

\begin{abstract}
The goal of this study was to examine the prevalence of chronic respiratory symptoms in potroom workers and to compare these results with changes in spirometric parameters. A modified questionnaire on respiratory symptoms from the British Medical Research Council was used to take the medical history data about respiratory symptoms. Spirometric parameters were determined on the same day (as a part of regular checkups) using the Jaeger spirometer. The study included 215 potroom workers from the aluminium factory in Podgorica, Montenegro. All subjects were men, but they differed in age and duration of work. The group used for comparison consisted of 81 unemployed male applicants for jobs in the factory who had never been exposed to this kind of air pollution before.

Potroom workers mostly complained of breathlessness associated with the workplace (56.7 \%) or weather changes (rain, cold wind, and humidity) (41.9\%) and of dyspnoea when climbing stairs (51.2 \%), but only $22.3 \%$ reported using medication to treat these episodes. Most workers reported to have been smoking at the time of the study (62.4\%). Spirometric data showed only insignificant variations compared to the expected values (CECA standards). Chronic obstructive pulmonary disease (COPD), characterised by FEV1/ VC $\%<88 \%$ was found in only 17 (7.9\%) potroom workers, while asthma was identified in 9 (4.2 \%). Although the prevalence of chronic respiratory symptoms reported by the examined potroom workers was quite high at the group level, they were not associated with ventilatory impairments.
\end{abstract}

KEY WORDS: aluminium industry, asthma, COPD, smoking, ventilatory impairments

A number of studies conducted in workers engaged in the electrolytic extraction of aluminium showed an increased incidence of respiratory impairments, particularly in prebaked anode technology. In 1979, Šarić et al. (1) published a paper on respiratory impairments in potroom workers who complained of dyspnoea, chest tightness, and wheezing after having started to work in potrooms. Some workers had these symptoms a few hours after work and/or when they went to bed later at night. In another paper (2), they suggested that acute bronchoconstriction occurring in

\footnotetext{
"This paper has partly been presented at the International Symposium Safety and Health at Work in Metal Industry: 2007 - Focus on Aluminium Industry" held in libenik, Croatia on 24-26 May 2007.
}

about $10 \%$ of workers might be based on an alteration in autonomic balance with vagal preponderance. In yet another study, performed later to clarify the potential role of atopy in the obtained findings, Šarić et al. (3) confirmed the involvement of nonspecific bronchial hyperreactivity in this particularly type of exposure.

Søyseth and Kongerud (4) studied the prevalence of respiratory disorders among aluminium potroom workers in relation to exposure to fluorides. According to them, the significant relationship between fluoride concentrations and bronchial hyperresponsiveness did not depend on the degree of dust exposure.

The aim of this study was to analyse the prevalence of respiratory symptoms in a group 
of potroom workers and to compare their symptoms with objective spirometric findings.

\section{SUBJECTS AND METHODS}

A regular checkup was conducted in 215 male workers engaged in the electrolytic extraction of aluminium (KAP - Podgorica, Montenegro). British Medical Research Council (BMRC) questionnaire (5) was used to obtain data about their respiratory symptoms.

The average subject age was $(37.7 \pm 7.6)$ years, average work experience (14.3 \pm 7.3$)$ years, average occupational exposure duration to dust (13.6 \pm 5.8$)$ years, and the average occupational exposure duration to potroom conditions was $(11.7 \pm 6.2)$ years.

We also examined 81 unemployed male workers who applied for the job in the same factory. They had never been exposed to fluorides, but they had similar social and educational background as the potroom workers. They were examined as a part of regular pre-employment screening, which took place at the same time as the checkup of the potroom workers. Their average age was $(25.7 \pm 4.6)$ years.

Age difference between the exposed and unexposed subjects was statistically significant (11.9 years; $p<0.05)$. Workers in the unexposed group were significantly taller: $(178.46 \pm 4.7)$ $\mathrm{cm}$ than the exposed subjects: $(175.8 \pm 6.6)$ $\mathrm{cm}$. Furthermore, total work experience in the unexposed group was significantly shorter than in the exposed group.

Medical history data for respiratory symptoms were taken using a translated and modified BMRC questionnaire (5) from 1965. This standardized questionnaire can be filled out by the worker himself or by trained medical personnel at the interview. In our study, the data were collected by trained nurses. Beside respiratory symptoms, the questionnaire contained questions about smoking and alcohol consumption. This kind of a questionnaire has already been used in studies of similar groups. Kongerud et al. (6) assessed the quality (sensitivity) and reliability of this questionnaire using a sample of 296 potroom workers.

Respiratory function tests were performed by a trained medical technician using a
FLOWSCREEN electronic spirometer (Jaeger). Measurements of the forced expiratory flow were adapted to environment temperature and pressure. During the testing, each subject was in an upright position and wearing a noseclip. For reference values, we used the 1983 CECA (7) standards. The results were interpreted using the guidelines issued by the 1985 Yugoslav Symposium for Unification and Standardization of Spirometric Tests (8).

\section{RESULTS}

Potroom workers mostly complained of breathlessness at workplace $(56.7 \%)$ or after weather changes (rain, cold wind, and humidity) $(41.9 \%)$ and of dyspnoea when climbing stairs (51.2\%). However, only $22.3 \%$ reported using medication to treat these episodes. Most subjects were active smokers (62.3\%). Subjects in the unexposed group reported significantly fewer respiratory symptoms (Table 1).

Over the previous three years, the exposed subjects had reported more respiratory diseases than the subjects from the unexposed group. Thirty-four exposed subjects had a history of pneumonia (15.8\%), while nine $(4.2 \%)$ were diagnosed asthma. Smoking was equally distributed between the exposed and the unexposed group. The exposed group had $13 \%$ of ex-smokers (Table 2).

Absolute values of spirometric parameters were significantly higher in unexposed subjects. Reasons for this could be younger age, greater height, and no occupational exposure to air pollution. Relative values which show the relationship between the obtained and expected values for general population were also significantly different for $\mathrm{FEV}_{1} \%$, VC \%, FVC \%, and PEF \% (Table 3).

Spirometric findings which indicate chronic obstruction of the airways or probability for the development of chronic obstructive pulmonary disease (COPD) were defined by criteria $\mathrm{FEV}_{1} /$ VC $\%<88 \%$ and $\mathrm{VC}<80 \%$ (Table 4 ).

Based on these criteria we found COPD in 17 $(7.9 \%)$ potroom workers. VC $<80 \%$ was found in $18(8.4 \%)$ potroom workers and four had decreased $\mathrm{FEV}_{1}$ NC \% as well as VC $<80 \%$. 
Table 1 Respiratory symptoms in potroom workers and in the unexposed group

\begin{tabular}{lccccccc}
\hline \multirow{2}{*}{ Parameter } & \multicolumn{2}{c}{$\begin{array}{c}\text { Exposed } \\
\text { subjects }\end{array}$} & \multicolumn{2}{c}{ Unexposed } & & & \\
& subjects & & p & OR $^{2}$ & RR $^{3}$ \\
\hline Cough for 3 months over the last 2 years & 82 & 38.1 & 2 & 2.5 & $<0.001$ & 24.5 & 1.56 \\
Expectoration for 3 months over the last 2 years & 67 & 31.2 & 6 & 7.4 & $<0.001$ & 5.6 & 1.38 \\
Stuffed nose during summer & 69 & 32.1 & 3 & 3.7 & $<0.001$ & 12.2 & 1.47 \\
Runny nose during summer & 42 & 19.5 & 2 & 2.5 & $<0.001$ & 9.71 & 1.36 \\
Runny nose during winter & 62 & 28.8 & 1 & 1.2 & $<0.001$ & 34.4 & 1.49 \\
Weather change influence on breathing & 90 & 41.9 & 3 & 3.7 & $<0.001$ & 18.7 & 1.57 \\
Dyspnoea climbing stairs & 110 & 51.2 & 4 & 4.9 & $<0.001$ & 20.2 & 1.67 \\
Dyspnoea on the flat ground & 45 & 20.9 & 1 & 1.2 & $<0.001$ & 21.2 & 1.44 \\
Wheezing & 92 & 42.8 & 2 & 2.5 & $<0.001$ & 29.5 & 1.43 \\
Breathlessness at work & 122 & 56.7 & 1 & 1.2 & $<0.001$ & 106.1 & 1.85 \\
Breathlessness outside work & 65 & 30.2 & 3 & 3.7 & $<0.001$ & 11.3 & 1.45 \\
Medicine use during the episode & 18 & 8.4 & 1 & 1.2 & $<0.05$ & 7.31 & 1.33 \\
Inhalator use during the episode & 19 & 8.8 & 1 & 1.2 & $<0.05$ & 7.75 & 1.33 \\
use of i.m. or i.v. medicine & 11 & 5.1 & 1 & 1.2 & NS & & \\
Total subjects & 215 & & 81 & & & & \\
\hline
\end{tabular}

${ }^{1}$ male unexposed job applicants for the same factory, significantly younger than the exposed subjects, ${ }^{2} \mathrm{OR}$ odds ratio, ${ }^{3} R R$ relative risk, ${ }^{4} \mathrm{NS}$ not significant.

Table 2 Smoking habit in potroom workers and in the unexposed group*

\begin{tabular}{lccccc}
\hline \multirow{2}{*}{ Smoking habits } & \multicolumn{2}{c}{ Exposed subjects } & \multicolumn{2}{c}{ Unexposed subjects } & p \\
& N & \% & N & \% & \\
\hline Active smokers & 134 & 62.3 & 51 & 63.0 & NS \\
Non-smokers & 53 & 24.7 & 30 & 37.0 & $<0.05$ \\
Ex smokers & 28 & 13.0 & 0 &. & 0.001 \\
Total subjects & 215 & & 81 & & \\
\hline
\end{tabular}

* male unexposed job applicants for the same factory, significantly younger than the exposed subjects

\section{DISCUSSION}

This study may be considered cross-sectional up to a point, as it has gathered data about subjects' exposure and health. This kind of studies is good for research of nonfatal chronic diseases, symptoms, and physiological functions. Their shortcoming is that they are a poor proof of cause and that they can be biased because of subject selection. In our case, the exposed group was selected in advance. Namely, a number of workers quit their position because of their respiratory symptoms. Our exposed subjects are what was left; they represent the survival population whose health and resistibility is above the average. In other words, it appears they fall ill less frequently (9). On the other hand, workers from the unexposed group were much younger.

Answering to the questionnaire, the exposed subjects complained more often of their respiratory symptoms than the unexposed subjects. At the same time, the ventilatory volumes in the exposed group showed values expected for their age, sex, and anthropometric characteristics. Slightly lower values were found in the flow-volume curve, which may point to changes in the small airways. The unexposed subjects had almost all parameters over the expected values (VC $113 \%$, FVC $108 \%$, and FEV $109 \%$ ). Compared with the results obtained by Pavlović in 1988 (10), who studied several groups of industrial workers, our relative values of spirometric parameters 
Table 3 Mean values of spirometric parameters in potroom workers and the unexposed group*

\begin{tabular}{|c|c|c|c|c|c|c|}
\hline \multirow[t]{2}{*}{ Parameter } & \multicolumn{2}{|c|}{$\begin{array}{c}\text { Exposed subjects } \\
\mathrm{N}=133\end{array}$} & \multicolumn{2}{|c|}{$\begin{array}{l}\text { Unexposed subjects } \\
\qquad \mathrm{N}=35\end{array}$} & \multirow[t]{2}{*}{ t-test } & \multirow[t]{2}{*}{$\mathrm{p}$} \\
\hline & $X$ & SD & $\mathrm{X}$ & SD & & \\
\hline VC liter & 5.0 & 0.8 & 5.6 & 0.7 & 4.68 & $0.00 *$ \\
\hline VC $\%$ & 99.4 & 13.4 & 113.8 & 52.7 & 2.84 & $0.00 *$ \\
\hline FVC liter & 4.9 & 0.9 & 5.6 & 0.7 & 4.58 & $0.00 *$ \\
\hline FVC \% & 102.4 & 15.4 & 108.7 & 13.5 & 2.23 & $0.03 *$ \\
\hline $\mathrm{FEV}_{1}$ liter & 4.0 & 0.8 & 4.7 & 0.7 & 4.38 & $0.00 *$ \\
\hline $\mathrm{FEV}_{1} \%$ & 102.4 & 18.7 & 109.4 & 15.7 & 2.05 & $0.04^{*}$ \\
\hline $\mathrm{FEV}_{1} / \mathrm{VC}$ & 79.8 & 10.2 & 82.0 & 7.4 & 1.19 & 0.24 \\
\hline $\mathrm{FEV}_{1} / \mathrm{NC} \%$ & 99.5 & 12.2 & 100.6 & 9.3 & 0.49 & 0.62 \\
\hline $\mathrm{MEF}_{25}$ liter & 2.0 & 0.8 & 2.3 & 0.8 & 2.40 & $0.02 *$ \\
\hline $\mathrm{MEF}_{25} \%$ & 89.5 & 32.8 & 92.3 & 30.8 & 0.45 & 0.65 \\
\hline $\mathrm{MEF}_{25-75}$ liter & 4.0 & 1.3 & 4.7 & 1.3 & 2.92 & $0.00 *$ \\
\hline $\mathrm{MEF}_{25-75} \%$ & 90.2 & 26.5 & 98.0 & 26.4 & 1.56 & 0.12 \\
\hline $\mathrm{MEF}_{50}$ liter & 4.8 & 1.4 & 5.7 & 1.6 & 3.19 & $0.00 *$ \\
\hline $\mathrm{MEF}_{50} \%$ & 93.7 & 27.2 & 103.9 & 28.3 & 1.96 & 0.05 \\
\hline PEF liter & 7.8 & 2.0 & 9.6 & 2.1 & 4.53 & $0.00 *$ \\
\hline PEF \% & 84.4 & 21.4 & 97.9 & 21.2 & 3.33 & $0.00 *$ \\
\hline
\end{tabular}

* male unexposed job applicants for the same factory, significantly younger than the exposed subjects

Parameters in bold are significantly different between the groups.

Table 4 Prevalence of decreased spirometric values in potroom workers and in the unexposed group*

\begin{tabular}{|c|c|c|c|c|c|}
\hline \multirow{2}{*}{ Parameter } & \multicolumn{2}{|c|}{ Exposed subjects } & \multicolumn{2}{|c|}{ Unexposed subjects } & \multirow{2}{*}{$\begin{array}{l}\text { Fischer's "exact" test } \\
\qquad<0.05\end{array}$} \\
\hline & $\mathrm{N}$ & $\%$ & $\mathrm{~N}$ & $\%$ & \\
\hline $\mathrm{VC}<80 \%$ & 18 & 8.4 & 1 & 1.2 & $0.05 ; \mathrm{OR}=7.31 ; \mathrm{Cl}_{95 \%}=0.95-55.7$ \\
\hline $\mathrm{FEV}_{1}<80 \%$ & 24 & 11.2 & 13 & 16.0 & NS \\
\hline $\mathrm{FEV}_{1} / \mathrm{NC} \%<88 \%$ & 17 & 7.9 & 2 & 2.5 & NS \\
\hline $\mathrm{PEF}<60 \%$ & 26 & 12.1 & 0 & . & $0.001 ; \mathrm{OR}=22.79 ; \mathrm{Cl}_{95 \%}=1.37-378.8$ \\
\hline $\mathrm{MEF}_{50}<60 \%$ & 19 & 8.8 & 1 & 1.2 & NS \\
\hline $\mathrm{MEF}_{25}<50 \%$ & 12 & 5.6 & 3 & 3.7 & $0.05 ; \mathrm{OR}=7.75 ; \mathrm{Cl}_{95 \%}=1.02-58.93$ \\
\hline $\mathrm{MEF}_{25-75}<60 \%$ & 17 & 7.9 & 1 & 1.2 & $\mathrm{NS} ; \mathrm{OR}=3.39$ \\
\hline
\end{tabular}

* male unexposed job applicants for the same factory, significantly younger than the exposed subjects

NS not significant

are $5 \%$ to $7 \%$ higher in both groups. This can be explained by different standards used. In our study, we used the 1983 CECA standards (7), which are, when it comes to VC and $\mathrm{FEV}_{1}$, lower than the $1972 \mathrm{CECA}$ standards used by Pavlović in his study.

Analysing medical history data in the group of potroom workers we found a high percentage of subjects with chronic respiratory symptoms, while in the unexposed group only $5.7 \%$ had the same symptoms. Although the latter were not occupationally exposed to respiratory agents, over $60 \%$ of them were active smokers.

Using the non-specific bronchoprovocation test with histamine, Godnić-Cvar (11) found bronchial hyperreactivity in $78 \%$ of 23 workers with asthma-like symptoms and in $52 \%$ of 27 symptom-free workers from an aluminium plant. The comparable number of hyperreactive workers in both groups was explained by the subjective experience of dyspnoea as well as by possible difference in the reactivity slope of the 
dose-response curve. Kongerud at al. (12) found symptoms of occupational asthma in 26 of 379 examined potroom workers. They also found a positive correlation between the symptoms and the obtained spirometric values.

In 1986, Kongerud et al. (13) conducted a longitudinal study which included 1679 male workers and 126 female workers employed in seven factories producing aluminium in Norway (total 1805 subjects). The subjects filled out a standard questionnaire on respiratory symptoms recommended by the BMRC, and were later interviewed about symptoms occurring on work days, non-working days, and during longer absences from work. Spirometric measurements were done during the first four hours of the work shift. The average age of the subjects was 32 years and the average exposure 6.5 years. Among them there were $60.5 \%$ smokers, $16 \%$ ex-smokers, and $23.5 \%$ non-smokers. These relations are very similar to those we found in our study. The authors suggested that a synergism of irritation from the cigarette smoke, fluorides, and other air pollution factors stimulated hyperreactors and "hard coughers to stop smoking". This explains the relatively high percent of ex-smokers in the exposed groups in our study as well. In a sample of 1760 potroom workers the same authors (14) found that $10.7 \%$ of subjects reported asthma-like symptoms associated with the working environment. They concluded that asthma-like symptoms were very important occupational health problems in the primary production of aluminium, which is in accordance with findings described in 1979 by Šarić et al. $(1,2)$. In our study, there were nine subjects with a previous history of asthma (4.2\%) among the potroom workers and none in the unexposed group.

However, Chan-Yeung at al. (15) did not find asthma cases among potroom workers in British Columbia, even though the control group in their investigation had higher $\mathrm{FEV}_{1}$, and complained less of cough and wheezing. These authors did not find a connection between exposure duration and respiratory symptoms in potroom workers.

The prevalence of COPD found in our study was only $7.9 \%$. We think that this is because the exposed group did not include all the potroom workers, such as workers on the sick leave (a number of whom was likely to have COPD) or workers with a degree of disability due to COPD or other disease who no longer worked in the potroom.

\section{CONCLUSION}

Potroom workers most commonly complained of breathlessness associated with the workplace or weather changes, and of dyspnoea when climbing stairs or waking up. However, only $22.3 \%$ reported using medicine to manage these symptoms. Most potroom workers were active smokers $(62.4 \%)$. Ventilatory volumes in potroom workers (VC \%, and FVC \%) were significantly lower than in the unexposed group. COPD, defined as $\mathrm{FEV}_{1} / \mathrm{VC} \%<88 \%$, was found in 17 potroom workers $(7.9 \%)$ and only in one unexposed subject $(1.2 \%)$. Furthermore, nine potroom workers $(4.2 \%)$ had a previous history of asthma at the time of the study.

Although the prevalence of individual respiratory symptoms reported by potroom workers was high, they were not associated with ventilatory impairments.

\section{REFERENCES}

1. Šarić M, Gomzi M, Hrustić O, Pauković R, Rudan P. Respiratory impairment in the electrolytic extraction of aluminium. Int Occup Environ Health 1979;42:17-21.

2. Šarić $M$, Žuškin E, Gomzi $M$. Bronchoconstriction in potroom workers. Br J Ind Med 1979;36:211-5.

3. Šarić M, Godnić Cvar J, Gomzi M, Štilinović L. The role of atopy in potroom workers' asthma. Am J Ind Med 1986;9:239-42.

4. Soyseth V, Kongerud J. Prevalence of respiratory disorders amoung aluminium potroom workers in relation to exposure to fluoride. $\mathrm{Br} \mathrm{J}$ Ind Med 1992;49:125-30.

5. Medical Research Council Committee on the Aetiology of Chronic Bronchitis. Standardized questionnaire on respiratory symptoms. Br Med J 1960;2:1665.

6. Kongerud J, Vale JR, Aalen O. Questionnaire reliability and validity for aluminium potroom workers. Scand J Work Environ Health 1989;15:364-70.

7. Quanjer PH, editor. Standardised lung function testing. Report working party. Standardisation of lung function tests. European Community for Coal and Steel, Luxembourg. Bull Eur Physiopathol Respir 1983;19:1-95

8. Pavičić F, Slavković V, Štangl B, Tabori Đ. Preporuke za unifikaciju i standardizaciju testova za ispitivanje ventilacijske sposobnosti pluća [Recommendations for unification and standardization of spirometric tests]. Golnik: 1985.

9. Krstev S. Osnovni principi epdemiologije u izučavanju specifičnih i nespecifičnih profesijskih respiratornih 
bolesti [Basic epidemiological principles of studying specific and non-specific respiratory diseases, in Serbian]. 5th Yugoslav Symposium on Pneumoconioses and Other Work-Related Respiratory Disesases (with international participation), Mataruška Banja, Serbia. Revija rada 1995;(special issue):49-55.

10. Pavlović M. Funkcijska ventilacija pluća industrijskih radnika [Ventilatory lung function in industrial workers]. [PhD thesis]. Belgrade: Medical School, University of Belgrade; 1988.

11. Godnić-Cvar J. Reaktivnost bronhija radnika iz elektrolize aluminija Alu-Swiss tehnologije [Bronchial reactivity in workers from an aluminium plant using AluSwiss technology, in Croatian]. Arh Hig Rada Toksikol 1986;37:311-7.
12. Kongerud J, Goyseth V, Burge S. Serial measurements of peak expiratory flow and responsiveness to methacholine in the diagnosis of aluminium potroom asthma. Thorax 1992;47:292-7.

13. Kongerud J, Gronnesby JK, Magnus P. Respiratory symptoms and lung function of aluminium potroom workers. Scand J Work Environ Health 1990;16:270-7.

14. Kongerud J, Boe J, Soyseth V, Naalsund A, Magnus P. Aluminium potroom asthma: the Norwegian expirience. Eur Respir J 1994;7:165-72.

15. Chan-Yeung M, Malo JL. Aetiological agents in occupational asthma. Eur Respir J 1994;7:346-71. 


\section{Sažetak}

\section{UČESTALOST DIŠNIH TEGOBA KOD RADNIKA U ELEKTROLIZI ALUIMINIJA I NJIHOVA POVEZANOST S PROMJENAMA SPIROMETRIJSKIH VRIJEDNOSTI}

Cilj rada bio je da se kod radnika u pogonu elektrolize aluminija ispita učestalost respiratornih simptoma koji imaju kroničan karakter i da se usporedi s učestalošću promjena spirometrijskih parametara kod istih osoba.

Anamnestički podaci o respiratornim simptomima uzimani su s pomoću modificiranog upitnika o respiratornim simptomima Britanskog savjeta za medicinska istraživanja. Spirometrijski parametri određivani su ispitanicima istoga dana (u sklopu njihova periodičnog pregleda) s pomoću spirometra marke Jaeger. Skupinu ispitanika činilo je 215 radnika pogona elektrolize Kombinata aluminijuma u Podgorici. Svi ispitanici bili su muškog spola, a različite dobi i dužine ekspozicije u elektrolizi. Istodobno je na jednak način ispitana skupina od 81 radnika također muškog spola, svi kandidati za radno mjesto u istoj tvornici, koji do tada nisu bili izloženi toj vrsti aeroonečišćenja.

Najčešći respiratorni simptomi kod radnika u elektrolizi bili su napadaji gušenja na radnome mjestu $(56,7 \%)$, dispneja pri usponu (51,2 \%) i utjecaj vremenskih prilika (kiša, hladan vjetar, povišena vlažnost zraka) na disanje (41,9\%). Međutim, tek je četvrtina (22,3\%) navela da pri napadu gušenja uzima neki od medikamenata. Među pregledanim radnicima bilo je najviše aktivnih pušača (62,3 \%). Istodobno, vrijednosti ventilacijskih volumena pokazale su samo neznatna odstupanja od očekivanih (po standardima CECA), a prevalencija kronične opstruktivne plućne bolesti (KOPB) definirana kriterijem $\mathrm{FEV}_{1} / \mathrm{NC} \%<88 \%$ nađena je samo kod $17(7,9 \%)$ radnika.

Na osnovi ovog istraživanja zaključili smo da je učestalost respiratornih simptoma koje prijavljuju radnici elektrolize aluminija visoka, ali da nju ne prate adekvatni pomaci objektivnih pokazatelja kakvi su spirometrijski.

KLJUČNE RIJEČI: astma, industrija aluminija, KOPB, pušenje, ventilacijska funkcija pluća

\section{CORRESPONDING AUTHOR:}

Ljiljana Cvejanov Kezunović

Medical School of Podgorica

Kruševac bb, 81000 Podgorica, Montenegro

E-mail:kezun123@cg.yu 